\title{
Development tendencies of regional disparities in the Slovak Republic
}

\author{
Radoslav Klamár $\mathrm{A}^{*}$ \\ Received: May 5, 2016 | Revised: September 9, 2016 | Accepted: September 14, 2016
}

\begin{abstract}
Presented paper deals with the issues of regional development and regional disparities in Slovakia in the years 2001-2014. Levelling respectively increase of regional disparities was evaluated through a set of 13 socio-economic indicators (gross birth rate, average monthly wage, monthly labour costs per employee, employment rate, unemployment rate, net monthly income and expenses per capita, completed dwellings, creation of GDP, labour productivity per employee in industry and construction, number of organizations focused on generating profit and number of freelancers) which were used in the territorial units at the level of self-governing regions of the Slovak Republic (NUTS III level). In terms of the evaluation and comparison of regional disparities were used the Gini coefficient and the coefficient of variation for mutual comparison and validation of divergent or convergent tendencies of regional disparities in Slovakia.
\end{abstract}

Keywords: regional development, regional disparities, regional policy, socio-economic indicators, the Gini coefficient, the coefficient of variation

\section{Introduction}

Slovakia, like other countries that underwent the transformation process, significantly began internally differentiate in terms of economic performance and potential of individual regions. Increase of regional disparities since the beginning of the 1990's is a major problem, what is evidenced by the fact that the presented plans for their reducing failed to realize. The complexity of the issue requires an interdisciplinary approach; however, the geographic approaches offer a synthetic view and underline spatiality in the evaluation.

In the broadest sense, disparities are understood as differences respectively inequalities of characters, events or processes which identification and comparison has any rational purpose (cognitive, psychological, social, economic, political) (Kutscherauer, 2008). They are the product of the operation of several factors, base on the quality and development of instantaneous availabilities of not only potentials, but also different positions, from which individual regions entered into the transformation process (Gajdoš, 2001).

According to an OECD study regional/spatial disparities reflect the level of the intensity of differences expression of the examined economic phenomenon observed within the regions of the country (OECD, 2002). There are several definitions and approaches to the issue of disparities as well as several possibilities for their evaluation. In spite of the examination of this phenomenon by increasingly wider group of theorists, its theoretical basis and specific systemic and methodological framework for examining is not enough sophisticated, yet (Kutscherauer, 2008).

In the presented paper, in accordance with Matlovič, Matlovičová (2011), we will consider regional disparities as differences on the stage of the socio-economic development of the regions, which we understand the self-governing regions as the territorial and administrative division of the SR.

\footnotetext{
A Department of Geography and Applied Geoinformatics, Faculty of Humanities and Natural Sciences, University of Presov, 17. novembra 1, 08001 Prešov, Slovakia; radoslav.klamar@unipo.sk

* Corresponding author: Radoslav Klamár, e-mail: radoslav.klamar@unipo.sk
} 


\section{Theoretical framework}

The issue of regional disparities has a rich history. Several economic theories tried to explain uneven state and development of the regions. At the beginning, dominated the theories of regional balance so-called neoclassical models, later the theories of regional imbalance were applied (Michálek, 2012a). The primary difference between the two groups is whether the authors are placing more importance to mechanisms and processes leading to levelling or on the contrary they considered differentiation processes and mechanisms to be stronger (accumulative, selective, concentration, etc.) (Blažek, Uhlíř, 2002).

The issue of regional disparities began to appear more frequently in times of economic crisis, especially with the decline of certain territories, cities and regions. Since then, cyclically alternated periods of increased interest in this issue with the periods when the issue of regional disparities was overshadowed, depending on the political situation in the country and the socio-economic situation in the various territories and regions (Michálek, 2012a).

Ancuţa (2012) states that the attention for territorial disparities became systematic starting with years 50 ( $2 \mathrm{O}^{\text {th }}$ century) when the society realized the social and political risks that the disparities can determine.

Dichotomy between convergence and divergence processes appeared in several academic works with this issue (Petrakos 1996; Dunfort, 1993; Orayen, et al. 2007; Petrakos, Artelaris, 2009). Particular attention should be paid to works of Felsenstein, Portnov (2005a, 2005b), dealing with issues of regional disparities in small countries (according to defined criteria, Slovakia is a small country), while the definition of the size of the countries is based on works of Easterly, Kraay (2000), Crowards (2002), Alesina, Spolaore (2003). Based on the work of Felsenstein, Portnov (2005a), the issue of regional disparities in small countries was also presented by Kutscherauer (2008).

In Slovakia, the issue of regional disparities got to the forefront in 1990's. In a period of dramatic transformation changes, occurred a significant territorial redistribution of the economy, a moderate concentration (redistribution) of jobs, but on the other hand the distribution of the population (housing) was unchanged (disparities were mainly conditioned demographically and led to a slight decline in the level of concentration) (Hampl, Müller 2011). Economic transformation brought increased dynamics of regional development, while differentiation trends as a consequence of operation of competing mechanisms were displayed (Matlovič, Matlovičová, 2011).

At the beginning of the transformation, individual regions had the different starting positions. They were different in potential for development as well as in development factors and their combinations that created a unique specific situation. In this context three most important geographical factors determining the development and reached status of regional socio-economic differentiation were defined by Hampl (2001): regional respectively territorial hierarchy, macro localization attractiveness and inappropriate economic specialization. According to Korec (2009) attention is paid to the four groups of factors having a decisive influence on regional development of Slovakia in the transformation period: the post-communist transformation (democratization of the society and the emergence of a market economy), the onset of post-industrial stage of society, endogenous factors "typical" for all post-communist countries, especially the $\mathrm{V}_{4}$ countries (territorial hierarchy, macro localization attractiveness and economic specialization of regions) and exogenous factors (including globalization expressed by localization of foreign direct investment).

The issue of regional disparities was elaborated in many works at the level of individual European countries. In the Czech Republic, it was Svatošová, Boháčková (2012), Měrtlová (2012), in Hungary region it was Nemes-Nagy (2006), Kebza, et al. (2015), in terms of life expectancy Uzzoli, Szilagyi (2009), in Slovenia Wostner (2005, In Felsenstein, Portnov 2005a), Croatian Puljiz, Maleković (2007), in Serbia Manic, et al. (2012) and in Romania Ancuţa (2012), Ianos, et al. (2013). The amount of work is focused on interregional comparisons within regions of $\mathrm{V}_{4}$ as Kožiak, et al. (2012), Zdražil, Kraft (2012), Poledníková (2014), Mariš (2016) as well as between EU member states: Petrakos (2001) and (2008), Hudec, Bilá (2008), Kallioras (2010), Poledníková, Lelková (2012), Horká (2012), Smętkowski, Wójcik (2012) and others.

\section{Methodological framework}

There are many approaches to measuring regional disparities. Several authors in their works specified in detail various methods of assessment and problems associated with them, respectively limitations resulting from the approach (Williamson, 1965; Felsenstein, Portnov, 2005a; Nemes-Nagy, 2006; Huang, Leung, 2009; Kutscherauer, et al., 2010; Michálek, 2012a; Hamada, 2016, etc.).

In assessing regional disparities, it is necessary to solve several methodological problems. It is necessary to define the observational level of the evaluated territorial units, determine the choice of adequate indicators for the assessment of regional disparities as well as to select the appropriate statistical tools for their measurement (Matlovič, et al., 2008; Matlovič, Matlovičová, 2011; Klamár, 2011). 
The first problem is the selection and the use of appropriate territorial division of observational units. As Buček, et al. (2010), Sloboda (2006) note, inappropriate observational units as well as indicators can lead to distortions - e.g. for regional disparities are considered urban-rural disparities, intra-regional disparities, social disparities etc. and also to an overestimation of the level of regional disparities.

When selecting appropriate hierarchical level of compared territorial units, the lower level of the observational unit, the more growing problem of the availability and relevance of observed data and time series. For this reason, the evaluation level was set at NUTS III (the self-governing region level), which provides several advantages: statistic (at regional level are monitored and assessed most regional statistical indicators as well as background information useful in assessing and measuring regional disparities), comparative (in many non-geographic-oriented research are regional disparities assessing at this hierarchical level), program (basic development documents at the regional level are linked to the regional level - Land Use Plan of the Self-Governing Region, Program of Economic and Social Development of the Region as indicated by the existence of higher territorial units which are identical to the regional level) (Klamár, 2011). Evaluation level of NUTS III also has its shortcomings and limitations. Matlovič, Matlovičová (2011) report the following problems: high internal heterogeneity of regions, the effect of the capital city and the effect of commuting.

Another important step is the selection of appropriate indicators. In selecting appropriate indicators, a limiting factor seems to be the limited availability of appropriate data. Many data are not systematically monitored respectively are not available at lower territorial units. Another problem is changing methodology of the construction of some indicators, what reduces the applicability in the time comparative analyses. Into the assessment of regional disparities enter many indicators, which are very different from each other by their nature and weight. Their selection and combination depend on point of view on the observed problem (a geographer focus on the different indicators than an economist or sociologist) as well as the nature of the research and hierarchical level. In terms of objectivity of the achieved results is required cross-section of the full range of indicators of the general-geographic, demographic, social, economic and environmental area (Matlovič, et al., 2008). The issue of the selection of indicators of regional disparities is discussed in detail in the work of Ancuţa (2012).

For the purpose of assessment of regional disparities was chosen the set of 13 assessment indicators, the choice of which is related to the degree of their information value as well as the possibility of obtaining the necessary background information in an adequate chronological time series from 2001 to 2014. The set of evaluation indicators was comprised of the following indicators to which the equal weight was imputed: gross birth rate, average monthly wage, monthly labour costs per employee, employment rate, unemployment rate, net monthly household income per capita, monthly household expenses per capita, completed dwellings per 1000 inhabitants, creation of GDP, labour productivity per employee in industry, labour productivity per employee in construction, the number of organizations focused on generating profit and the number of freelancers per 1000 inhabitants.

After the determination of the observational units and the choice of evaluation indicators followed the selection of statistical tools for the measurement of disparities. The literature provides several tools to measure them. Felsenstein, Portnov (2005a) reports the Gini coefficient, the coefficient of variation, Theil index, Atkinson index, Hoover coefficient and Coulter coefficient. Similar evaluation methods are also mentioned by Hamada (2016) and Štika (2004), who pays attention to the possibility of using fuzzy c cluster analysis. Brülhart, Traeger (2005, In Michálek, 2012b) recommended to use in addition to traditional indices also entropy rate (index). Matlovič, Matlovičová (2011) used in the evaluation the method of distance from a fictitious object.

The most commonly used include the Gini coefficient and the coefficient of variation which were used by Wostner (2005, In Felsenstein, Portnov, 2005a), Puljiz, Maleković (2007), Kallioras (2010), Smętkowski (2013) and others. For purposes of this research were also used just mentioned factors.

The coefficient of variation (CV) is a tool for comparative analyses and it is a relative measure of dispersion derived from the standard deviation $\sigma$ (the ratio of the standard deviation and the mean)

$$
C V=\frac{\sigma}{\bar{x}}=\frac{\sqrt{\frac{\sum_{i=1}^{n}\left(x_{i}-\bar{x}\right)^{2}}{n}}}{\bar{x}}
$$

The coefficient of variation allows correlating the variability of variables with different values (clean the standard deviation by the height of the mean).

The second statistical measure was the Gini coefficient, coefficient of concentration (IG), which originated as a tool to measure pension inequality. It ranges between o (absolute equality) to 1 (absolute inequality).

$$
I G=\frac{1}{2 n^{2} \bar{x}} \sum_{i=1}^{n} \sum_{j=1}^{n}\left(x_{i}-x_{j}\right)
$$


where

$n$ is the total number of observational (territorial) units, $x_{i}$ is the value of the indicator in the i-territorial unit, $x_{j}$ is the value of the indicator in the j-territorial unit and $\bar{x}$ is the arithmetic mean of the indicator $x$.

The choice of two statistical measures (the coefficient of variation and the Gini coefficient) to measure regional disparities and the comparison of their results guarantee that analyzed trend of regional disparities is real and corresponds to the state of their development in Slovakia.

\section{Results}

The Slovak Republic is the part of Central Europe. It borders with Poland in the north, the Czech Republic and Austria in the west, Hungary in the south and Ukraine in the east. By its area of $49035 \mathrm{~km}^{2}$ and the number of 5415949 inhabitants ( $31^{\text {st }}$ December 2014), is considered to be smaller country of Europe. Slovakia was established on $1^{\text {st }}$ January 1993, since $1^{\text {st }}$ May 2004, it has been a member of the European Union, since $21^{\text {st }}$ December 2007 is has been included in the Schengen area and on $1^{\text {st }}$ January 2009, it adopted the Euro currency. The capital city Bratislava has 419678 inhabitants, the second largest city Košice 239464 inhabitants and the third city Prešov 90187 inhabitants ( $31^{\text {st }}$ December 2014).

In terms of NUTS classification, Slovakia is divided into 4 NUTS II regions (Bratislava region, Western Slovakia, Central Slovakia and Eastern Slovakia) and 8 NUTS III regions (the Bratislava self-governing region, the Trnava self-governing region, the Trenčín self-governing region, the Nitra self-governing region, the Žilina self-governing region, the Banská Bystrica self-governing region, the Prešov self-governing region and the Košice self-governing region - Figure 1). From these regions, the largest area have the Banská Bystrica self-governing region $\left(9454 \mathrm{~km}^{2}\right)$, the Prešov self-governing region $\left(8973 \mathrm{~km}^{2}\right)$ and the Žilina selfgoverning region $\left(6808 \mathrm{~km}^{2}\right)$. In terms of population, the most populous region is the Prešov self-governing region (818,916 inhabitants), the Košice self-governing region (795,565 inhabitants) and the Žilina selfgoverning region $(690,420$ inhabitants). On the lower NUTS IV level, there are 79 districts and 2933 municipalities.

Evaluation of the development of regional disparities in Slovakia in the period 2001-2014, was supported by a set of 13 above mentioned indicators. The selection of indicators was determined by the requirement of their availability in the examined period as well as the need to reflect changes in the stage of the socioeconomic development of regions. For better clarity and simplification in the text below were used abbreviated forms of the following self-governing regions (regions at the level of NUTS III): the Bratislava selfgoverning region (BA region), the Trnava self-governing region (TT region), the Trenčín self-governing region (TN region), the Nitra self-governing region (NT region), the Žilina self-governing region (ZA region), the Banská Bystrica self-governing region (BB region), the Prešov self-governing region (PO region) and the Košice self-governing region (KE region). In the case of the Gini coefficient, it was shortened in the form of IG and in the coefficient of variation it was CV.

\section{Gross birth rate}

Natural movement of population represented by a gross birth rate is a fundamental demographic indicator in the evaluation of regional disparities.

The birth rate has a decisive role in the reproductive process. It is an indicator of reproductive vitality and perspective of the regions. The year 2003 was an important milestone in the demographic development, when for the first time were increased the number of live births and the birth rate in Slovakia after 23 years (Matlovič, et al., 2008).

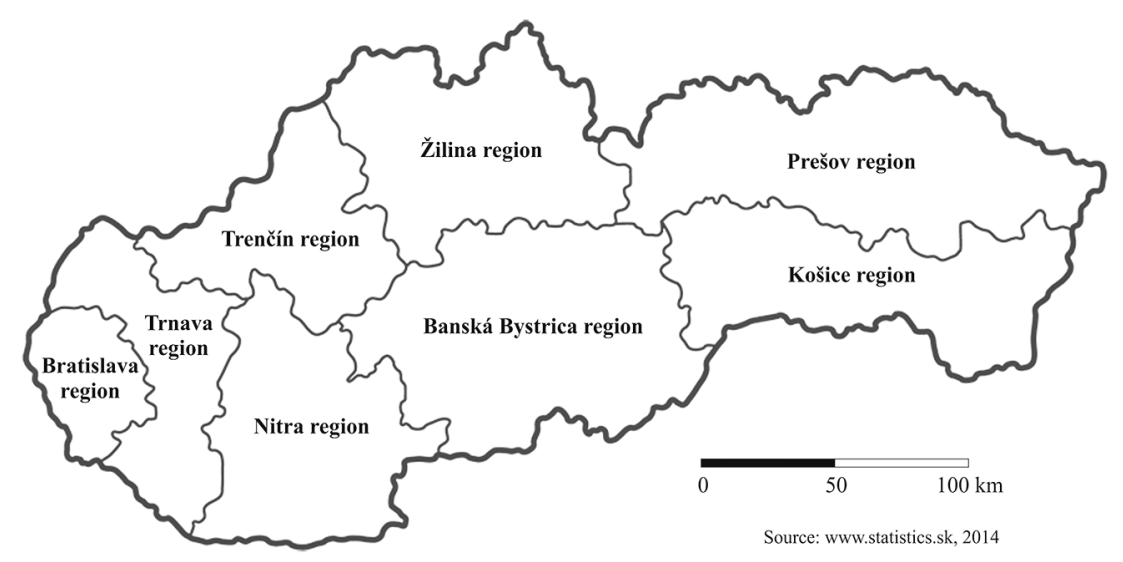

Figure 1. The self-governing regions (NUTS III) in Slovakia in 2014 
Table 1. Development of the gross birth rate (\%o) in the self-governing regions in the Slovak Republic in the years 2001-2014

\begin{tabular}{|c|c|c|c|c|c|c|c|c|c|c|c|c|c|c|}
\hline Reg. & 2001 & 2002 & 2003 & 2004 & 2005 & 2006 & 2007 & 2008 & 2009 & 2010 & 2011 & 2012 & 2013 & 2014 \\
\hline BA & 7,70 & 7,61 & 8,50 & 9,06 & 9,75 & 9,79 & 10,38 & 11,14 & 11,99 & 12,09 & 12,91 & 12,33 & 11,99 & 12,48 \\
\hline TT & 8,31 & 8,21 & 8,45 & 8,96 & 8,95 & 9,12 & 8,82 & 9,59 & 9,90 & 9,91 & 10,03 & 9,48 & 9,45 & 9,64 \\
\hline TN & 8,11 & 7,93 & 7,88 & 8,40 & 8,48 & 8,46 & 8,69 & 9,03 & 9,65 & 9,92 & 9,94 & 8,67 & 9,11 & 8,65 \\
\hline NT & 8,10 & 8,14 & 8,25 & 8,33 & 8,62 & 8,51 & 8,58 & 9,21 & 9,62 & 9,27 & 9,66 & 8,71 & 8,47 & 8,82 \\
\hline ZA & 10,21 & 10,19 & 10,12 & 10,37 & 10,25 & 10,05 & 10,09 & 10,64 & 11,11 & 10,92 & 11,32 & 10,45 & 10,08 & 9,91 \\
\hline BB & 9,04 & 9,05 & 9,20 & 9,71 & 9,76 & 9,47 & 9,65 & 9,76 & 10,57 & 10,31 & 10,14 & 9,13 & 9,25 & 9,24 \\
\hline PO & 12,26 & 11,96 & 11,87 & 12,19 & 12,25 & 11,98 & 11,84 & 12,48 & 13,47 & 13,07 & 12,73 & 11,63 & 11,51 & 11,41 \\
\hline KE & 11,10 & 11,28 & 11,52 & 11,82 & 11,79 & 11,72 & 11,74 & 12,16 & 13,08 & 12,67 & 12,65 & 11,17 & 10,73 & 10,67 \\
\hline IC & 0,0901 & 0,0910 & 0,0824 & 0,0776 & 0,0722 & 0,0692 & 0,0677 & 0,0661 & 0,0712 & 0,0674 & 0,0640 & 0,0725 & 0,0647 & 0,0686 \\
\hline CV & 0,1774 & 0,1778 & 0,1618 & 0,1509 & 0,1405 & 0,1350 & 0,1302 & 0,1263 & 0,1366 & 0,1287 & 0,1258 & 0,1378 & 0,1229 & 0,1321 \\
\hline
\end{tabular}

Source: www.statistics.sk, own calculation

The gross birth rate developed differentially in the self-governing regions of Slovakia. Development, economic prosperity and social stability are beginning to be observed in this area. In economically developed regions of western Slovakia (TT region, TN region, NT region and ZA region) was noticeable a slight rise in the birth rate during the reporting period. On the other side were economically depressed regions of south-eastern Slovakia, where there was a slight decrease respectively stagnation of the birth rate. Special case represents the Bratislava self-governing region whose birth rate was the lowest in Slovakia in $2001(7.70 \%)$, but at the end of the reporting period it had the highest value of $12.48 \%$. An increase by $62.1 \%$ was mainly caused by the attractiveness of the capital Bratislava and its job opportunities for young people who gradually after solving the primary problems with the occupation, housing and thereby ensuring a sufficient social status start the families and boost the birth rate. The gradual trend of balancing the selfgoverning region disparities was confirmed by the decrease of the value of IG from 0.0901 to 0.0686 and CV from 0.1774 to 0.1321 .

\section{Average monthly wage}

The second used indicator was the average monthly wage. It is one of the basic socio-economic indicators, by which differentiated development of the regions can be evaluated. It is the average gross nominal monthly wage in enterprises with 20 or more employees. It is calculated to natural persons and does not include business income.

The average monthly wage was growing over the entire reporting period. In Slovakia, there was recorded an increase from the value of $384 €(2001)$ to $784 €$ (2014); however, the growth at the regional level was differentiated. While the highest growth was in TN region by $109.9 \%$, ZA region by $106.6 \%$ and TT region by $103.7 \%$, the lowest was in KE region by $98.2 \%$ and PO region by $100.3 \%$.

In the overall assessment during the reporting period can be noted two different trends of disparities development. In the first half of the reporting period (2001-2006) characterized by the economic boom, can be observed the increase of regional disparities between the regions, as is evident by the growth of IG (0.0729 $=>0.0847)$ and CV (0.1719 $\Rightarrow>0.1901)$. In the

Table 2. Development of the average monthly wage $(€)$ in the self-governing regions in the Slovak Republic in the years 2001-2014

\begin{tabular}{|c|c|c|c|c|c|c|c|c|c|c|c|c|c|c|}
\hline Reg. & 2001 & 2002 & 2003 & 2004 & 2005 & 2006 & 2007 & 2008 & 2009 & 2010 & 2011 & 2012 & 2013 & 2014 \\
\hline BA & 540 & 585 & 627 & 698 & 770 & 825 & 877 & 944 & 970 & 991 & 1001 & 1029 & 1049 & 1107 \\
\hline TT & 379 & 414 & 444 & 487 & 534 & 584 & 636 & 676 & 689 & 705 & 735 & 736 & 745 & 772 \\
\hline TN & 371 & 404 & 423 & 462 & 502 & 544 & 583 & 630 & 635 & 657 & 687 & 724 & 750 & 779 \\
\hline NT & 346 & 379 & 403 & 440 & 473 & 511 & 551 & 606 & 625 & 636 & 662 & 661 & 680 & 705 \\
\hline ZA & 363 & 400 & 418 & 462 & 504 & 546 & 589 & 646 & 657 & 686 & 707 & 726 & 732 & 750 \\
\hline BB & 354 & 386 & 406 & 442 & 483 & 520 & 560 & 600 & 605 & 635 & 652 & 675 & 706 & 730 \\
\hline PO & 328 & 359 & 378 & 416 & 438 & 468 & 498 & 546 & 573 & 594 & 608 & 613 & 636 & 657 \\
\hline KE & 391 & 433 & 469 & 512 & 557 & 595 & 627 & 672 & 684 & 716 & 726 & 735 & 758 & 775 \\
\hline IG & 0,0729 & 0,0722 & 0,0768 & 0,0788 & 0,0850 & 0,0847 & 0,0834 & 0,0794 & 0,0781 & 0,0761 & 0,0731 & 0,0735 & 0,0707 & 0,0732 \\
\hline CV & 0,1719 & 0,1675 & 0,1751 & 0,1819 & 0,1926 & 0,1901 & 0,1861 & 0,1810 & 0,1809 & 0,1756 & 0,1663 & 0,1704 & 0,1650 & 0,1744 \\
\hline
\end{tabular}

Source: www.statistics.sk, own calculation 
Table 3. Development of the monthly labour costs per employee $(€)$ in the self-governing regions in the Slovak Republic in the years 2001-2013

\begin{tabular}{|c|c|c|c|c|c|c|c|c|c|c|c|c|c|}
\hline Reg. & 2001 & 2002 & 2003 & 2004 & 2005 & 2006 & 2007 & 2008 & 2009 & 2010 & 2011 & 2012 & 2013 \\
\hline BA & 834,9 & 894,8 & 971,5 & 1137,1 & 1059,7 & 1174,8 & 1243,2 & 1348,3 & 1410,8 & 1475,0 & 1529,0 & 1592,0 & 1642,0 \\
\hline TT & 588,1 & 629,0 & 727,8 & 767,2 & 802,8 & 861,3 & 985,7 & 1048,4 & 1063,7 & 1061,0 & 1102,0 & 1130,0 & 1127,0 \\
\hline $\mathrm{TN}$ & 582,2 & 643,8 & 662,7 & 677,7 & 781,5 & 835,1 & 909,3 & 942,1 & 964,6 & 986,0 & 1032,0 & 1082,0 & 1104,0 \\
\hline NT & 537,6 & 6 & 687,6 & 6 & 7 & 761,2 & 824,0 & 917,8 & 928,5 & 970,0 & 964,0 & 0 &, 0 \\
\hline ZA & 593,0 & 639,5 & 654,9 & 717,1 & 773,0 & 825,2 & 920,0 & 978,3 & 978,7 & 1020,0 & 1081,0 & 1114,0 & 1149,0 \\
\hline $\mathrm{BB}$ & 571,8 & 623,5 & 679,6 & 744,3 & 776,0 & 775,0 & 847,3 & 911,6 & 952,5 & 965,0 & 1024,0 & 1016,0 & 1065,0 \\
\hline $\mathrm{PO}$ & 531,3 & 580,5 & 632,0 & 652,6 & 709,7 & 728,8 & 810,4 & 878,0 & 856,4 & 862,0 & 905,0 & 942,0 & 982,0 \\
\hline $\mathrm{KE}$ & 669,1 & 693,8 & 733,1 & 855,0 & 882,3 & 955,8 & 1029,6 & 1089,5 & 1041,5 & 1075,0 & 1102,0 & 1142,0 & 1192,0 \\
\hline IG & 0,0726 & 0,0621 & 0,0646 & 0,0906 & 0,0610 & 0,0789 & 0,0740 & 0,0710 & 0,0738 & 0,0765 & 0,0764 & 0,0758 & 0,0756 \\
\hline $\mathrm{CV}$ & 0,1611 & 0,1470 & 0,1501 & 0,2013 & 0,1340 & 0,1660 & 0,1505 & 0,1504 & 0,1647 & 0,1743 & 0,1733 & 0,1745 & 0,1754 \\
\hline
\end{tabular}

Source: www.statistics.sk, own calculation

next period, significantly affected by the global crisis, can be observed the change of direction to levelling respectively to decline of disparities (IG - 0.0834 $=>0.0732, \mathrm{CV}-0.1861=>0.1744)$. In this sense, however, the levelling of regional disparities was not the result of reaching up of economically weaker regions, but more significant economic problems of developed regions which were affected by global economic crisis that hit in a larger scale. Overall, the level of disparities at the beginning and at the end of the period is more or less balanced.

\section{Monthly labour costs per employee}

Average monthly labour costs are defined as the total labour costs per month divided by the corresponding number of employees working on full-time. Total labour costs are the sum of the costs per defined unit of time which the employer expends on obtaining and education of the workforce, the remuneration for work and ensuring the social needs of workforce pursuant to commitments.

Monthly labour costs per employee like the average monthly wage grew for the entire reporting period (national average of the Slovak Republic - 613.5 $€$ (2001) $=>1163.3$ (2013). In spite of some increase of disparities, stabilization with minor fluctuations can be observed (particularly in the period 2001 - 2004). IG changed during the entire reporting period only minimal (from $0.0726 \Rightarrow$ 0.0756) also CV (0.1611 $\Rightarrow>0.1754)$. Long-term within this indicator, the last place took $\mathrm{PO}$ region with the value of $982 €$ (2013), what represents only $59.8 \%$ of the costs of BA region and $84.4 \%$ of the SR.

\section{Employment rate}

Employment rate is an important economic indicator of the performance of the regional economy. This is evidenced by the fact that employment policy of the EU in a medium-term horizon set to achieve employment rate of $70 \%$ and higher in Europe's regions.

Employment rate is calculated based on the proportion of employed persons aged $15-64$ years to the total number of persons aged $15-64$ years. Persons on maternity leave and parental leave and persons working on the performance contract performed outside employment are excluded (Statistical Yearbook of the Slovak Republic, 2012).

Table 4. Development of the employment rate (\%) in the self-governing regions in the Slovak Republic in the years 2001-2014

\begin{tabular}{|c|c|c|c|c|c|c|c|c|c|c|c|c|c|c|}
\hline Reg. & 2001 & 2002 & 2003 & 2004 & 2005 & 2006 & 2007 & 2008 & 2009 & 2010 & 2011 & 2012 & 2013 & 2014 \\
\hline BA & 68,5 & 67,1 & 68,2 & 67,7 & 69,6 & 69,8 & 70,9 & 72,1 & 71,2 & 68,5 & 70,3 & 71,6 & 70,7 & 70,1 \\
\hline TT & 59,6 & 60,7 & 61,9 & 62,7 & 64,2 & 65,2 & 66,7 & 68,0 & 66,1 & 64,5 & 64,6 & 64,5 & 62,9 & 65,4 \\
\hline TN & 59,7 & 60,7 & 62,7 & 62,6 & 62,7 & 64,3 & 63,8 & 65,0 & 62,1 & 61,5 & 61,7 & 61,6 & 62,7 & 62,6 \\
\hline NT & 52,5 & 51,0 & 52,7 & 55,2 & 55,9 & 58,3 & 61,1 & 64,1 & 59,3 & 58,0 & 59,8 & 60,1 & 60,8 & 62,1 \\
\hline ZA & 56,2 & 57,8 & 57,8 & 56,5 & 57,4 & 59,6 & 60,4 & 62,4 & 59,3 & 56,8 & 57,4 & 57,7 & 57,9 & 59,9 \\
\hline BB & 54,5 & 52,6 & 53,1 & 51,0 & 52,8 & 54,4 & 54,9 & 56,4 & 54,4 & 55,8 & 57,8 & 58,4 & 57,5 & 59,6 \\
\hline PO & 53,1 & 54,6 & 54,8 & 52,9 & 53,7 & 55,9 & 58,3 & 58,2 & 56,7 & 55,2 & 54,4 & 54,4 & 54,9 & 57,0 \\
\hline KE & 51,0 & 51,3 & 52,5 & 50,3 & 49,2 & 51,5 & 52,8 & 55,3 & 55,1 & 53,0 & 52,9 & 53,6 & 54,8 & 57,0 \\
\hline IG & 0,0493 & 0,0513 & 0,0515 & 0,0574 & 0,0613 & 0,0544 & 0,0519 & 0,0493 & 0,0487 & 0,0458 & 0,0489 & 0,0493 & 0,0440 & 0,0368 \\
\hline CV & 0,0996 & 0,0992 & 0,0997 & 0,1099 & 0,1167 & 0,1027 & 0,0979 & 0,0931 & 0,0951 & 0,0888 & 0,0944 & 0,0966 & 0,0873 & 0,0717 \\
\hline
\end{tabular}


The development of the employment rate in Slovakia had a positive trend, while during the reporting period 2001-2014 increased from $56.8 \%$ to $61.7 \%$. Although this value is close to the EU 27 average $(64.1 \%$, 2012), the level of $70 \%$, which is the standard in economically developed countries of Europe (Finland, Sweden, Norway, Denmark, the Netherlands, Germany and others) was reached and since 2007 has been regularly exceeded only by the Bratislava region. A more significant increase was recorded in the regions with increased investment activity (NT region by $18.3 \%$, KE region by $11.8 \%$ and TT region by $9.7 \%$ ), although since 2008 , can be identified the stagnation and a slight drop in employment. The lowest employment rate was recorded in underdeveloped regions of south-eastern Slovakia, where the employment rate increased moderately (PO region by $7.3 \%, \mathrm{BB}$ region by $9.4 \%)$.

The development of regional disparities copied the periods of the economic development and stagnation. The increase was recorded in 2001-2005 (IG - 0.0493 $\Rightarrow 0.0613, \mathrm{CV}-0.0996=>0.1167)$. Subsequently, there was recorded decline to the level of IG - 0.0368 and CV- 0.0717. Overall, there was recorded a decline of regional disparities in this indicator over the reporting period.

\section{Unemployment rate}

By the character, unemployment rate is at the intersection of economic and social indicators. It is measured as a share of disposable number of registered unemployed to the number of economically active inhabitants.

The unemployment rate is an indicator that immediately reacts to economic changes. The economic boom as well as the recession is immediately reflected on its rate. From the point of the long term, the unemployment rate culminated in 1999. Since this period, consistently with the economic progresses of the
Slovak Republic is recorded a decline of the unemployment, what is confirmed by the values during the reporting period. A significant milestone was the beginning of the economic crisis in late 2008. Until this year, the unemployment rate had declined from the value of $18.33 \%$ (2001) to $7.83 \%$ (2008). From this year there was a constant growth until $2012(14.25 \%)$ and then a slight stabilization and decline $(12.05 \%$ - 2014).

In spite of the fact that regional disparities between 2001 and 2014 were comparable (IG - 0.1924 and 0.1874 ; CV - 0.3776 and 0.3579 ), the culmination of regional disparities was recorded in the last pre-crisis year 2007 (IG - 0.3048, CV - 0.5867).

In the context of regional disparities compared with other indicators, disparities between regions of the Slovak Republic in the unemployment rate are abysmal. $\mathrm{PO}, \mathrm{KE}$ and $\mathrm{BB}$ regions have nearly three times higher unemployment rate compared to BA region and two times compared to TT and TN regions.

\section{Net monthly income and expenses per capita}

Net monthly income per capita closely related to two previous indicators characterizing the labour market. Ability to find a job and adequate work placement has a significant impact on the assessment of the economic indicator.

Net monthly income consists of net earnings (excluding income tax and compulsory contributions), social income, other income (income from property, income from institutions and income from private persons, including income in kind, income from the sale of agricultural products and income from abroad), the positive difference between the selected savings and the submitted deposits and the positive difference between a selected and paid loans.

As an indirect indicator of purchasing power can be used in the analysis of the business environment and it gives us the idea of the standard of living in the region (Matlovič, Matlovičová, 2011).

Table 5. Development of the unemployment rate (\%) in the self-governing regions in the Slovak Republic in the years 2001-2014

\begin{tabular}{|c|c|c|c|c|c|c|c|c|c|c|c|c|c|c|}
\hline Reg. & 2001 & 2002 & 2003 & 2004 & 2005 & 2006 & 2007 & 2008 & 2009 & 2010 & 2011 & 2012 & 2013 & 2014 \\
\hline BA & 5,79 & 5,18 & 3,97 & 3,39 & 2,60 & 2,29 & 1,98 & 2,27 & 4,36 & 4,63 & 5,41 & 5,72 & 6,17 & 6,13 \\
\hline TT & 15,51 & 12,99 & 11,05 & 8,83 & 7,15 & 5,22 & 4,30 & 4,29 & 8,37 & 8,17 & 8,88 & 9,43 & 9,16 & 8,03 \\
\hline TN & 12,70 & 10,91 & 9,87 & 8,09 & 6,80 & 5,19 & 4,50 & 4,95 & 10,13 & 9,51 & 9,95 & 10,89 & 10,74 & 9,56 \\
\hline NT & 23,12 & 21,51 & 19,07 & 14,80 & 11,39 & 9,09 & 7,10 & 7,41 & 11,72 & 11,76 & 13,27 & 14,08 & 12,52 & 11,21 \\
\hline ZA & 16,38 & 14,74 & 13,23 & 11,12 & 9,33 & 7,03 & 5,55 & 6,20 & 10,89 & 10,86 & 11,91 & 12,79 & 12,51 & 10,91 \\
\hline BB & 23,59 & 23,77 & 22,75 & 19,50 & 18,32 & 16,12 & 14,10 & 14,25 & 19,19 & 18,86 & 19,83 & 20,81 & 18,26 & 17,22 \\
\hline PO & 23,96 & 23,00 & 19,57 & 17,50 & 15,77 & 13,68 & 12,05 & 12,86 & 18,29 & 17,75 & 18,95 & 20,66 & 19,35 & 17,45 \\
\hline KE & 25,55 & 24,26 & 22,16 & 18,89 & 17,50 & 15,18 & 13,02 & 13,50 & 17,30 & 16,78 & 18,76 & 19,58 & 17,23 & 15,92 \\
\hline IG & 0,1924 & 0,2151 & 0,2304 & 0,2405 & 0,2693 & 0,2951 & 0,3048 & 0,2945 & 0,2191 & 0,2164 & 0,2092 & 0,2074 & 0,1855 & 0,1874 \\
\hline CV & 0,3776 & 0,4165 & 0,4418 & 0,4562 & 0,5098 & 0,5619 & 0,5867 & 0,5672 & 0,4195 & 0,4113 & 0,3991 & 0,3953 & 0,3523 & 0,3579 \\
\hline
\end{tabular}

Source: www.statistics.sk, own calculation 
Table 6. Development of the net monthly income per capita $(€)$ in the self-governing regions in the Slovak Republic in the years 2001-2013

\begin{tabular}{|c|c|c|c|c|c|c|c|c|c|c|c|c|c|}
\hline Reg. & 2001 & 2002 & 2003 & 2004 & 2005 & 2006 & 2007 & 2008 & 2009 & 2010 & 2011 & 2012 & 2013 \\
\hline BA & 270,4 & 280,5 & 294,5 & 340,5 & 326,2 & 381,3 & 407,9 & 465,6 & 441,3 & 442,8 & 452,5 & 468,5 & 487,0 \\
\hline TT & 201,2 & 212,2 & 229,1 & 239,2 & 253,6 & 286,0 & 335,4 & 367,6 & 359,4 & 373,2 & 376,7 & 384,6 & 388,0 \\
\hline TN & 202,3 & 212,8 & 233,0 & 221,1 & 242,2 & 282,8 & 309,8 & 338,5 & 347,0 & 355,5 & 364,5 & 371,0 & 376,0 \\
\hline NT & 206,0 & 211,8 & 226,7 & 230,3 & 287,2 & 285,3 & 321,7 & 349,1 & 345,3 & 344,0 & 361,8 & 352,2 & 354,0 \\
\hline ZA & 201,7 & 214,2 & 219,6 & 235,3 & 241,2 & 277,1 & 307,2 & 336,5 & 345,5 & 337,5 & 356,3 & 367,0 & 362,0 \\
\hline BB & 211,3 & 216,5 & 229,2 & 229,3 & 242,0 & 276,0 & 310,0 & 331,5 & 323,8 & 335,3 & 349,6 & 353,1 & 356,0 \\
\hline PO & 195,0 & 205,0 & 209,7 & 221,4 & 222,8 & 247,5 & 287,5 & 309,2 & 327,0 & 305,5 & 327,1 & 327,7 & 328,0 \\
\hline KE & 212,3 & 233,7 & 246,0 & 235,4 & 243,7 & 269,6 & 304,9 & 341,0 & 331,1 & 322,1 & 330,4 & 333,8 & 337,0 \\
\hline IG & 0,0452 & 0,0457 & 0,0492 & 0,0607 & 0,0601 & 0,0570 & 0,0502 & 0,0579 & 0,0457 & 0,0570 & 0,0496 & 0,0554 & 0,0602 \\
\hline CV & 0,1131 & 0,1098 & 0,1099 & 0,1619 & 0,1293 & 0,1374 & 0,1143 & 0,1342 & 0,1072 & 0,1192 & 0,1074 & 0,1194 & 0,1332 \\
\hline
\end{tabular}

Source: www.statistics.sk, own calculation

Net monthly income in Slovakia increased during the entire reporting period from the value of $212.5 €$ (2001) to $373.5 €(2013)$. This increase was significantly spatially differentiated, as can be evidenced by a slight increase of regional disparities (IG $-0.0452=>0.0602$, $\mathrm{CV}-0.1131=>0.1332)$. The highest disparities were during the greatest economic development of Slovakia in 2004 (IG - 0.0607, CV - 0.1619). After this year there was a gradual decline in regional disparities until 2011 and subsequently stagnation and a slight increase in 2013. The highest net monthly income per capita was traditionally in BA region and in the regions of western Slovakia. In this part of Slovakia, was recorded their highest increase (TT region by $92.8 \%$ and $\mathrm{TN}$ region by $85.8 \%$ ). At the opposite site, there were the most lagging regions of the Slovak Republic, in which was recorded the lowest growth of income (KE region by $58.7 \%$, PO region by $68.2 \%$ and BB region by $68.5 \%$ ).

The opposite of the net monthly income are the net monthly expenses. It consists of consumption expenses (i.e. expenses on food, clothing, housing, recreation, and culture, etc.) and other costs (taxes and fees to the authorities) without compulsory contributions to insurance companies, returned cash donations outside the households and paid loans.

Similarly, in the indicator of the net monthly expenses can be observed their growth in the average of the Slovak Republic for the entire reporting period from $208.8 €$ to $323.8 €$. Spatial differentiation similarly in the previous indicator culminated in 2004 (IG - $0.0723, \mathrm{CV}$ - 0.1536), but the overall, comparing the years 2001 and 2013, it had changed relatively less (IG $0.0438=>0.0601$, CV - $0.1071=>0.1335$ ).

The highest net monthly expenses are directly proportional to the net monthly income, what is evident by the highest value in BA region. The highest growth of expenses was in TT region (by $72.6 \%$ ), BA region (60.9\%) and ZA region (60.6\%). At the opposite site, there were the regions of eastern Slovakia (KE region - by $42.7 \%$, and PO region - by $43.9 \%$ ), where the expenses were the lowest.

\section{Completed dwellings}

Quality and affordable housing is an important determinant affecting the quality of life as well as the factors

Table 7. Development of the net monthly expenses per capita $(€)$ in the self-governing regions in the Slovak Republic in the years 2001-2013

\begin{tabular}{|c|c|c|c|c|c|c|c|c|c|c|c|c|c|}
\hline Reg. & 2001 & 2002 & 2003 & 2004 & 2005 & 2006 & 2007 & 2008 & 2009 & 2010 & 2011 & 2012 & 2013 \\
\hline BA & 262,3 & 264,2 & 278,5 & 317,3 & 313,7 & 350,7 & 405,1 & 416,8 & 384,5 & 393,0 & 400,9 & 409,3 & 422,0 \\
\hline TT & 191,8 & 204,7 & 222,1 & 243,6 & 242,0 & 284,7 & 293,4 & 318,7 & 301,0 & 327,1 & 329,4 & 335,0 & 331,0 \\
\hline TN & 204,5 & 210,5 & 234,5 & 211,5 & 223,1 & 283,3 & 286,6 & 317,3 & 307,7 & 301,0 & 333,3 & 325,8 & 324,0 \\
\hline NT & 207,7 & 212,3 & 225,8 & 224,6 & 251,7 & 276,9 & 304,5 & 336,0 & 306,3 & 319,3 & 318,8 & 313,8 & 311,0 \\
\hline ZA & 199,3 & 210,4 & 215,3 & 225,7 & 248,6 & 276,9 & 308,0 & 335,5 & 308,5 & 304,3 & 325,5 & 333,1 & 320,0 \\
\hline BB & 207,3 & 204,7 & 222,0 & 257,3 & 232,4 & 269,5 & 300,2 & 318,7 & 283,7 & 292,9 & 303,3 & 313,4 & 312,0 \\
\hline PO & 194,5 & 196,7 & 204,7 & 205,3 & 210,2 & 256,0 & 275,1 & 268,3 & 265,4 & 258,5 & 286,0 & 285,3 & 280,0 \\
\hline KE & 203,2 & 219,1 & 234,4 & 215,0 & 246,7 & 262,6 & 279,9 & 305,3 & 308,4 & 286,6 & 292,2 & 289,3 & 290,0 \\
\hline IG & 0,0438 & 0,0412 & 0,0444 & 0,0723 & 0,0585 & 0,0450 & 0,0566 & 0,0596 & 0,0498 & 0,0618 & 0,0528 & 0,0560 & 0,0601 \\
\hline CV & 0,1071 & 0,0967 & 0,0958 & 0,1536 & 0,1251 & 0,1034 & 0,1351 & 0,1285 & 0,1118 & 0,1270 & 0,1104 & 0,1183 & 0,1335 \\
\hline
\end{tabular}


Table 8. Development of the number of completed dwellings per 1000 inhabitants in the self-governing regions in the Slovak Republic in the years 2001-2014

\begin{tabular}{|c|c|c|c|c|c|c|c|c|c|c|c|c|c|c|}
\hline Reg. & 2001 & 2002 & 2003 & 2004 & 2005 & 2006 & 2007 & 2008 & 2009 & 2010 & 2011 & 2012 & 2013 & 2014 \\
\hline BA & 3,19 & 4,75 & 4,09 & 5,57 & 7,74 & 7,10 & 9,37 & 9,02 & 9,61 & 8,31 & 5,98 & 7,46 & 5,78 & 5,76 \\
\hline TT & 2,78 & 3,72 & 4,33 & 3,03 & 3,71 & 4,77 & 4,82 & 4,89 & 4,67 & 4,82 & 4,71 & 4,32 & 4,19 & 4,18 \\
\hline TN & 1,56 & 2,14 & 2,69 & 2,45 & 2,62 & 2,08 & 1,91 & 2,45 & 3,45 & 2,82 & 2,07 & 2,48 & 2,51 & 2,78 \\
\hline NT & 1,37 & 1,75 & 2,38 & 1,98 & 1,53 & 1,91 & 1,79 & 2,02 & 2,24 & 2,17 & 1,98 & 2,40 & 2,40 & 2,40 \\
\hline ZA & 1,87 & 3,03 & 2,66 & 2,37 & 2,87 & 2,61 & 2,83 & 3,07 & 3,54 & 3,15 & 2,77 & 2,42 & 2,44 & 2,83 \\
\hline BB & 1,60 & 2,17 & 1,52 & 1,24 & 1,17 & 1,41 & 1,43 & 1,53 & 2,35 & 1,36 & 1,53 & 1,28 & 1,55 & 1,44 \\
\hline PO & 2,05 & 2,44 & 2,24 & 1,69 & 2,20 & 1,69 & 2,13 & 1,96 & 1,94 & 1,97 & 1,91 & 1,76 & 2,39 & 2,02 \\
\hline KE & 1,28 & 1,72 & 1,56 & 1,14 & 1,22 & 1,03 & 1,33 & 1,64 & 1,30 & 1,59 & 1,64 & 1,52 & 1,76 & 1,53 \\
\hline IC & 0,1764 & 0,1957 & 0,1977 & 0,2737 & 0,3408 & 0,3441 & 0,3737 & 0,3407 & 0,3300 & 0,3292 & 0,2721 & 0,3142 & 0,2288 & 0,2523 \\
\hline CV & 0,3499 & 0,3907 & 0,3881 & 0,5822 & 0,7457 & 0,7329 & 0,8535 & 0,7661 & 0,7253 & 0,7057 & 0,5795 & 0,6913 & 0,4903 & 0,5081 \\
\hline
\end{tabular}

Source: www.statistics.sk, own calculation

influencing labour mobility, which is a serious problem of the Slovak economy. Housing issue and its solution is considerably differentiated within the Slovak regions.

Evaluated indicator focused on the number of completed dwellings per 1000 inhabitants belongs to indicators pointing to the highest disparities between the regions of the Slovak Republic. The highest number of dwellings was completed in BA region - 5.76 apartments (2014), while in comparison to the national average (2.87 apartments) it was more than two times higher. TT region (4.18 apartments) also contributed to a significant differentiation while other regions were under the Slovak average (at least it was in $\mathrm{BB}$ region - 1.44, KE region 1.53 and $\mathrm{PO}$ region - 2.02). Both of mentioned regions (BA and TT region) contributed by $43.1 \%$ share in the total number of completed dwellings in Slovakia. In the most developed regions and throughout the entire reporting period, the highest increase was recorded (BA region $-80.4 \%$, TN region $-78.0 \%$, and NT region $-75.4 \%$ ). At the opposite site, there were economically underdeveloped regions, where the increase was only by $19.2 \%$ (KE region) and even a decline in $\mathrm{PO}$ region (from 2.05 apartments $=>2.02)$ and $\mathrm{BB}$ region $(1.60=>1.44)$.
These values were also visibly reflected in the growth of IG (0.1764 $=>0.2523)$ and CV (0.3499 $\Rightarrow$ 0.5081 ), with the highest disparities in 2007 (IG - 0.3737, CV - 0.8535).

\section{Gross domestic product}

Gross domestic product is considered to be the most representative economic indicators of regional disparities. It assesses the degree of maturity of the economy, the living standards of inhabitants and intensity of development. Regional GDP is calculated as the sum of added values for individual sectors in the region, and taxes on products decreased by subsidies on products. For the purpose of comparison, the regional GDP is converted per capita. In spite of its relative complexity, it does not reflect the effect of commuting that results in overestimation of GDP per capita in the region (mostly the region with the capital city), to which people commute from surrounding regions.

The formation of GDP per capita was significantly differentiated in the reporting period. The most significant growth in disparities was in 2005, respectively 2006, when they were at the level of 0.2305 (IG) and

Table 9. Development of the gross domestic product $(€)$ per capita in the self-governing regions in the Slovak Republic in the years 2001-2013

\begin{tabular}{|c|c|c|c|c|c|c|c|c|c|c|c|c|c|}
\hline Reg. & 2001 & 2002 & 2003 & 2004 & 2005 & 2006 & 2007 & 2008 & 2009 & 2010 & 2011 & 2012 & 2013 \\
\hline BA & 13886,4 & 15466,6 & 16977,9 & 18957,7 & 22270,3 & 23784,0 & 26918,5 & 28503,3 & 28318,3 & 29241,2 & 32150,1 & 32281,5 & 33259,6 \\
\hline TT & 6435,8 & 6844,1 & 7874,2 & 8852,0 & 9895,6 & 12427,0 & 13675,3 & 14177,6 & 12811,1 & 13633,7 & 14500,1 & 14918,6 & 14790,6 \\
\hline TN & 5919,2 & 6254,8 & 6946,3 & 7770,6 & 8081,4 & 9536,8 & 10502,7 & 11205,4 & 10285,4 & 10744,5 & 11455,2 & 11791,3 & 11929,1 \\
\hline NT & 5337,2 & 5786,7 & 6546,5 & 7416,3 & 8125,9 & 8755,7 & 9509,0 & 10481,1 & 9823,6 & 10077,6 & 11584,6 & 11973,9 & 11919,2 \\
\hline ZA & 5209,6 & 5591,9 & 6037,7 & 6792,8 & 7536,8 & 8270,2 & 9553,2 & 10775,7 & 10028,2 & 10746,4 & 11199,8 & 11506,6 & 11663,0 \\
\hline BB & 5303,2 & 5912,0 & 6484,3 & 6909,9 & 6565,3 & 7536,9 & 8450,2 & 9317,3 & 8479,0 & 8973,7 & 9125,1 & 9495,5 & 9884,8 \\
\hline PO & 3843,3 & 4237,2 & 4577,8 & 5021,7 & 5384,6 & 5583,0 & 6259,0 & 7258,3 & 6700,5 & 6860,7 & 7589,8 & 7933,4 & 8097,5 \\
\hline KE & 5836,1 & 6175,5 & 6706,4 & 7392,4 & 7720,6 & 8599,0 & 9361,5 & 10180,5 & 9069,9 & 9580,6 & 10098,7 & 10461,4 & 10629,4 \\
\hline IG & 0,1902 & 0,1922 & 0,1961 & 0,1998 & 0,2265 & 0,2305 & 0,2311 & 0,2164 & 0,2314 & 0,2305 & 0,2362 & 0,2292 & 0,2282 \\
\hline CV & 0,4775 & 0,4960 & 0,4966 & 0,4985 & 0,5653 & 0,5376 & 0,5483 & 0,5226 & 0,5729 & 0,5635 & 0,5805 & 0,5612 & 0,5710 \\
\hline
\end{tabular}

Source: www.statistics.sk, own calculation 
$0.5653(\mathrm{CV})$. In the following period, the increase in disparities was stabilized, but for the entire reporting period disparities were deepened (IG - $0.1902=>0.2282, C V$ $-0.4775=>0.5710$ ). These disparities are documented by different GDP creation in individual regions. While in $\mathrm{BA}$ region it was 2.4 times above the national average, other regions, except TT region $(105.7 \%$ of the national average), did not reached the Slovak average. At the opposite site, there were traditionally the regions of eastern-south Slovakia where PO region reached only $57.7 \%$ of the national average and $24.3 \%$ of BA region, $\mathrm{BB}$ (70.5\% of the national average) and KE region (75.8\% of the national average). Moreover, the last mentioned regions also had the lowest increase in GDP per capita during the reporting period (KE region by $82.1 \%, \mathrm{BB}$ region by $86.4 \%$, PO region by $110.7 \%$ ), which is significantly less compared with $129.8 \%$ in TT region and $139.5 \%$ in BA region.

\section{Labour productivity}

Labour productivity represents real output divided by labour inputs. Labour productivity increases thanks to improved technologies, greater job skills and capi- tal deepening. In Central and Eastern Europe, Slovakia is in first place in this area mainly thanks to the high labour productivity in industry, which is the backbone of the Slovak economy. Industry steadily increased its production in maintaining the number of employees, while in the period from 2001 to 2010 was its average annual growth rate at the level of $7.5 \%$, what was more than in any other EU country. Within productivity is further attention focused on labour productivity in industry and construction.

Since 2001, labour productivity in industry continues to grow. Its average value in Slovakia in 2014 was $178894 €$ (an increase by $196.2 \%$ compared to 2001 ). The values of the examined indicator grew differentially in individual regions of Slovakia. While in regions of localization of foreign investment, productivity grew faster than the national average (ZA region by $351.9 \%$, TT region by $309.4 \%$ ) in underdeveloped regions it was only by $105.9 \%$ (BB region), $113.1 \%$ (KE region) and $114.5 \%$ (PO region).

Above mentioned different development in regions of the Slovak Republic was also reflected in the amount of regional disparities (IG $-0.2259 \Rightarrow 0.2847$,

Table 10. Development of the labour productivity per employee in industry $(€)$ in the self-governing regions in the Slovak Republic in the years 2001-2014

\begin{tabular}{|c|c|c|c|c|c|c|c|c|c|c|c|c|c|c|}
\hline Reg. & 2001 & 2002 & 2003 & 2004 & 2005 & 2006 & 2007 & 2008 & 2009 & 2010 & 2011 & 2012 & 2013 & 2014 \\
\hline BA & 136208 & 148413 & 215024 & 216720 & 211568 & 278520 & 266139 & 397928 & 339214 & 398014 & 446869 & 466627 & 431164 & 386996 \\
\hline TT & 59115 & 64804 & 70142 & 82739 & 91522 & 133396 & 154943 & 187027 & 199555 & 221032 & 227207 & 248087 & 248584 & 242073 \\
\hline TN & 39521 & 41087 & 46232 & 49034 & 55945 & 62096 & 65588 & 73415 & 66287 & 85320 & 102857 & 109874 & 116906 & 116470 \\
\hline NT & 43560 & 50169 & 50395 & 50438 & 52493 & 57349 & 64712 & 99273 & 102326 & 120255 & 114971 & 113358 & 121633 & 125171 \\
\hline ZA & 53074 & 58657 & 59241 & 68170 & 71689 & 72061 & 106705 & 139776 & 132043 & 183708 & 196160 & 217519 & 237096 & 239820 \\
\hline BB & 43773 & 43703 & 46345 & 53356 & 58136 & 63095 & 67404 & 78752 & 68618 & 77347 & 84585 & 84997 & 88567 & 90120 \\
\hline PO & 39922 & 39262 & 41097 & 45379 & 46784 & 48805 & 53031 & 63741 & 61992 & 74772 & 82698 & 84919 & 86532 & 85616 \\
\hline KE & 67998 & 71065 & 80688 & 90052 & 104956 & 112527 & 115455 & 135815 & 116023 & 139026 & 145949 & 155589 & 154655 & 144887 \\
\hline IC & 0,2259 & 0,2383 & 0,3016 & 0,2890 & 0,2770 & 0,3244 & 0,2981 & 0,3325 & 0,3235 & 0,3170 & 0,3187 & 0,3252 & 0,3035 & 0,2847 \\
\hline CV & 0,5338 & 0,5529 & 0,7577 & 0,6938 & 0,6277 & 0,7402 & 0,6373 & 0,7455 & 0,6919 & 0,6687 & 0,6940 & 0,6954 & 0,6306 & 0,5807 \\
\hline
\end{tabular}

Source: www.statistics.sk, own calculation

Table 11. Development of labour productivity per employee in construction sector $(€)$ in the self-governing regions in the Slovak Republic in the years 2001-2014

\begin{tabular}{|c|c|c|c|c|c|c|c|c|c|c|c|c|c|c|}
\hline Reg. & 2001 & 2002 & 2003 & 2004 & 2005 & 2006 & 2007 & 2008 & 2009 & 2010 & 2011 & 2012 & 2013 & 2014 \\
\hline BA & 34040 & 35441 & 43135 & 52114 & 64034 & 64034 & 77339 & 88880 & 88645 & 88895 & 87423 & 90960 & 89232 & 94046 \\
\hline TT & 23246 & 31285 & 32152 & 37881 & 40955 & 40955 & 50003 & 48645 & 44012 & 51845 & 55841 & 42286 & 40003 & 42445 \\
\hline TN & 20932 & 23179 & 26588 & 33582 & 38206 & 38206 & 49924 & 61239 & 55896 & 40621 & 42313 & 42701 & 36296 & 40028 \\
\hline NT & 21032 & 26280 & 29928 & 36327 & 38525 & 38525 & 44486 & 50906 & 45423 & 45456 & 49623 & 42964 & 38324 & 41260 \\
\hline ZA & 21460 & 24407 & 28540 & 32533 & 45130 & 45130 & 54159 & 56665 & 46825 & 47025 & 45702 & 43128 & 47786 & 47964 \\
\hline BB & 19179 & 20686 & 22827 & 26177 & 27896 & 27896 & 38319 & 44811 & 47985 & 60789 & 59798 & 43580 & 46848 & 55064 \\
\hline PO & 18403 & 19482 & 20378 & 22459 & 25294 & 25294 & 31020 & 39255 & 36733 & 38442 & 37729 & 39729 & 33253 & 31258 \\
\hline KE & 32225 & 36719 & 33440 & 39740 & 49346 & 49346 & 64237 & 64296 & 61214 & 53612 & 77506 & 56983 & 53450 & 56047 \\
\hline IG & 0,1195 & 0,1268 & 0,1215 & 0,1310 & 0,1524 & 0,1513 & 0,1474 & 0,1342 & 0,1412 & 0,1416 & 0,1569 & 0,1351 & 0,1664 & 0,1735 \\
\hline CV & 0,2499 & 0,2416 & 0,2373 & 0,2568 & 0,2974 & 0,2964 & 0,2844 & 0,2702 & 0,3016 & 0,3013 & 0,3057 & 0,3429 & 0,3718 & 0,3765 \\
\hline
\end{tabular}


Table 12. Development of the number of organizations focused on generating profit per 1000 inhabitants in the self-governing regions in the Slovak Republic in the years 2001-2014

\begin{tabular}{|c|c|c|c|c|c|c|c|c|c|c|c|c|c|c|}
\hline Reg. & 2001 & 2002 & 2003 & 2004 & 2005 & 2006 & 2007 & 2008 & 2009 & 2010 & 2011 & 2012 & 2013 & 2014 \\
\hline BA & 32,71 & 29,62 & 33,42 & 37,20 & 42,25 & 47,60 & 52,30 & 63,64 & 69,11 & 78,89 & 89,67 & 95,32 & 102,46 & 108,73 \\
\hline TT & 8,85 & 10,14 & 10,49 & 11,93 & 13,63 & 15,50 & 17,00 & 19,63 & 21,17 & 23,44 & 25,58 & 26,88 & 29,82 & 31,86 \\
\hline TN & 10,15 & 9,36 & 9,90 & 12,87 & 14,08 & 15,30 & 16,00 & 18,32 & 18,54 & 19,80 & 20,87 & 22,12 & 24,45 & 26,15 \\
\hline NT & 7,65 & 7,55 & 8,05 & 9,41 & 10,52 & 12,10 & 13,40 & 16,52 & 17,60 & 20,36 & 22,40 & 24,75 & 28,86 & 31,19 \\
\hline ZA & 9,07 & 9,11 & 9,68 & 10,75 & 12,15 & 13,40 & 14,30 & 16,89 & 17,56 & 19,26 & 20,38 & 22,07 & 25,36 & 27,69 \\
\hline BB & 10,06 & 8,75 & 9,36 & 10,91 & 12,27 & 13,50 & 14,70 & 16,53 & 17,36 & 19,28 & 20,12 & 21,44 & 23,87 & 26,15 \\
\hline PO & 7,65 & 7,22 & 7,95 & 9,18 & 10,52 & 11,60 & 12,40 & 14,35 & 14,97 & 16,28 & 17,40 & 18,43 & 19,91 & 21,77 \\
\hline KE & 10,28 & 9,52 & 10,02 & 11,51 & 12,75 & 13,80 & 14,80 & 16,70 & 17,09 & 18,97 & 20,05 & 21,19 & 22,92 & 24,85 \\
\hline IG & 0,2501 & 0,2360 & 0,2436 & 0,2398 & 0,2387 & 0,2407 & 0,2441 & 0,2507 & 0,2605 & 0,2684 & 0,2859 & 0,2858 & 0,2828 & 0,2767 \\
\hline CV & 0,6980 & 0,6509 & 0,6926 & 0,6587 & 0,6663 & 0,6777 & 0,6912 & 0,7257 & 0,7545 & 0,7785 & 0,8255 & 0,8214 & 0,7940 & 0,7788 \\
\hline
\end{tabular}

Source: www.ueos.sk/mvrr.sk/isvov/, own calculations

CV $-0.5338 \Rightarrow 0.5807)$, while the highest disparities were in 2008 (IG - 0.3335, CV - 0.7455) at the end of the period of economic boom.

Labour productivity in the construction sector grew in the SR for the entire reporting period, but compared with the industry it was not a significant increase (only by $114.2 \%$ ). In this indicator were not observed such significant regional disparities as in industry, but this is the only indicator where the highest values of regional disparities were recorded in the last reporting year - 2014 (IG - 0.1735, CV - 0.3765) mainly due to intensive building activities in $\mathrm{BA}$ region (184.4\% of average of the SR). Other regions were at the level of Slovak average (KE region - 109.9\%, BB region $-104.9 \%$ ) or below the average (PO region - only $61.3 \%$ of the Slovak average).

\section{Business structure}

Very important area of development of Slovak regions includes the business sector and its structure. This economic level was evaluated through two selected indicators - the number of organizations focused on generating profit and the number of freelancers. In terms of comparison were these two indicators recalculated per 1000 inhabitants.

Organizations focused on generating profit represent organizations registered under the Commercial Code and subsidized organizations, whose income is exceed by more than $50 \%$ of the costs. The figures include only economically active units.

The number of organizations focused on generating profit recalculated per 1000 inhabitants in Slovakia during the reporting period more than tripled (from 12.05 in 2001 to 37.3 in 2014). According to the development of IG $(0.2501=>0.2767)$ and CV $(0.6980$ $=>0.8214$ ), increase is noticeable, but not as dramatic; however, compared with disparities in the other indicators, disparities between the regions of the SR are fairly substantial. While BA region in 2014 had the value of $291.5 \%$ of the average of the SR, other regions did not reach even the average (the most in TT region $-85.4 \%$, and NT region $-83.6 \%$, the least in $\mathrm{PO}$ region $-58.4 \%$, KE region $-66.6 \%$ and $\mathrm{BB}$ region - $70.1 \%$ ).

The second important indicator of business structures is the number of freelancers calculated per 1000

Table 13. Development of the number of freelancers per 1000 inhabitants in the self-governing regions in the Slovak Republic in the years 2001-2014

\begin{tabular}{|c|c|c|c|c|c|c|c|c|c|c|c|c|c|c|}
\hline Reg. & 2001 & 2002 & 2003 & 2004 & 2005 & 2006 & 2007 & 2008 & 2009 & 2010 & 2011 & 2012 & 2013 & 2014 \\
\hline BA & 87,0 & 77,0 & 85,2 & 94,4 & 94,0 & 91,2 & 103,3 & 96,7 & 94,9 & 92,7 & 93,3 & 89,2 & 87,01 & 81,2 \\
\hline TT & 55,3 & 55,6 & 60,9 & 66,0 & 68,1 & 72,4 & 78,6 & 76,9 & 76,5 & 74,6 & 72,4 & 69,8 & 67,02 & 64,3 \\
\hline TN & 49,7 & 50,3 & 57,1 & 63,6 & 64,5 & 70,2 & 73,8 & 74,1 & 73,2 & 72,7 & 70,9 & 68,0 & 65,86 & 62,4 \\
\hline NT & 49,7 & 47,9 & 53,5 & 57,8 & 59,9 & 65,5 & 70,9 & 69,3 & 69,0 & 67,8 & 66,9 & 65,0 & 63,84 & 61,8 \\
\hline ZA & 54,7 & 56,1 & 63,0 & 69,6 & 72,1 & 76,7 & 82,1 & 81,8 & 80,7 & 80,3 & 85,0 & 78,7 & 77,94 & 76,6 \\
\hline BB & 44,0 & 43,0 & 48,9 & 53,7 & 56,5 & 59,7 & 66,2 & 63,9 & 63,0 & 63,1 & 60,1 & 57,8 & 57,30 & 54,8 \\
\hline PO & 42,9 & 44,0 & 50,4 & 56,2 & 57,6 & 61,2 & 69,5 & 72,1 & 70,3 & 69,7 & 67,6 & 64,6 & 63,06 & 59,7 \\
\hline KE & 40,0 & 38,9 & 43,3 & 46,3 & 46,6 & 47,7 & 54,5 & 51,6 & 50,2 & 49,9 & 47,0 & 45,1 & 44,85 & 42,2 \\
\hline IC & 0,1250 & 0,1118 & 0,1077 & 0,1110 & 0,1073 & 0,0981 & 0,0942 & 0,0917 & 0,0923 & 0,0896 & 0,1041 & 0,1003 & 0,0978 & 0,0985 \\
\hline CV & 0,2803 & 0,2304 & 0,2218 & 0,2287 & 0,2173 & 0,1900 & 0,1896 & 0,1795 & 0,1805 & 0,1750 & 0,2021 & 0,1956 & 0,1922 & 0,1930 \\
\hline
\end{tabular}


inhabitants. Freelancers are persons conducting business under the Trade Act.

The last indicator - development of the number of freelancers per 1000 inhabitants, together with the gross birth rate are only two indicators where can be observed a decrease in regional disparities (IG - 0.1250 $=>0.0985, C V-0.2803=>0.1930)$. In this single indicator occurred real convergence thanks to the improvement of evaluated indicator in economically weaker regions (mostly $\mathrm{PO}$ region by $39.2 \%$, $\mathrm{BB}$ region by $24.6 \%$ ), while in TT region only by $16.3 \%$ and in BA region even a decrease by $6.6 \%$. In less developed regions, however, it was to some extent due to lower absorption ability of business subjects to absorb new workers (the question of levy payment and regularity of job offer) so people were forced to establish licences to carry on a business and work in the invoice. In spite of this fact, the most freelancers per 1000 inhabitants were in BA region (129.1\% of the Slovak average) and ZA region (102.2\%), while KE region (67.1\% of the Slovak average) and $\mathrm{BB}$ region $(87.1 \%)$ overdue.

\section{Overall assessment}

\section{of regional disparities in Slovakia}

Based on the assessment of individual indicators mentioned above is clear that the development of individual regions in Slovakia was significantly differentiated in the recent period. Transformation period that end-

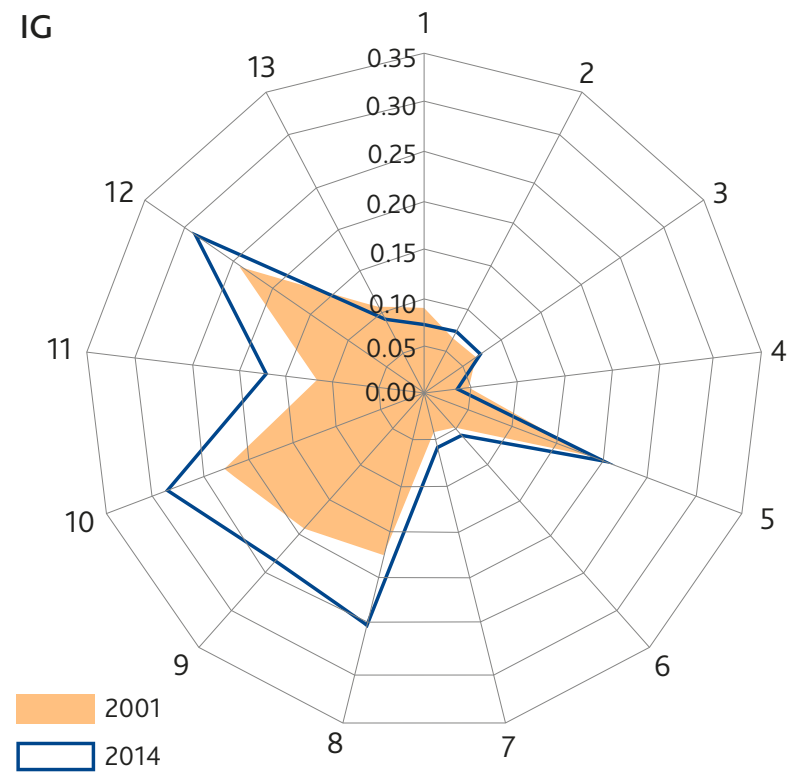

ed in 2004 after Slovakia's accession into the EU significantly strengthened divergence tendencies in Slovakia. The increase of regional disparities continued during two coming years (2004-2006), in which were recorded the biggest disparities within five indicators (average monthly wage, monthly labour costs per employee, employment rate, net monthly income and expenses per capita). In the following year 2007 , two indicators cumulated (unemployment rate, completed dwellings per 1000 inhabitants), while in 2008 reached its maximum labour productivity per employee in industry. If we add the highest degree of regional disparities in the gross birth rate in 2002 and the number of freelancers per 1000 inhabitants in 2001, it is clear that the greatest acceleration of the growth of regional disparities was in the period of the general economic development of Slovakia. With the onset of the global crisis in the world in 2008 and Slovakia in 2009, the situation changed and the deepening was slowed respectively stopped. After this period, only three indicators (GDP per capita - 2011, the organization focused on generating profit per 1000 inhabitants - 2011 and labour productivity per employee in construction - 2014) reached the maximum in disparities. For all other 10 indicators was recorded stabilization respectively a slight decrease of regional disparities.

If the reporting period was evaluated as a whole, it would be clear that in 9 out of 13 indicators was re-

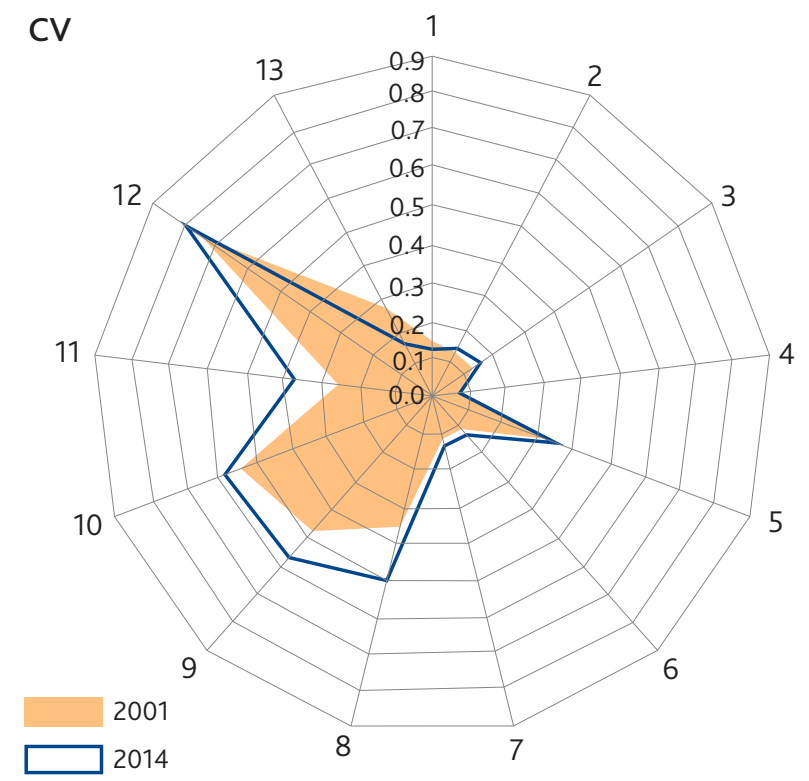

Figures 2-3. Comparison of the Gini coefficient and coefficient of variation in the year 2001 and 2014. Explanation: 1- the gross birth rate, 2 - the average monthly wage, 3 - monthly labour cost per employee 4 - employment rate, 5 unemployment rate, 6 - net monthly income per capita, 7 - net monthly expenses per capita, 8 - completed dwellings per 1000 inhabitants, 9 - creation of GDP per capita, 10 - labour productivity per employee in industry, 11 - labour productivity per employee in construction, 12 - organizations focused on generating profit per 1000 inhabitants, 13 number of freelancers per 1000 inhabitants.

Note: For indicators - monthly labour costs per employee, net monthly income per capita, net monthly expenses per capita, gross domestic product per capita was used the last available year with data (2013)

Source: www.statistics.sk, www.ueos.sk/mvrr.sk/isvov/, own calculation 
corded overall increase of disparities (the fact is supported by an increase of the flat structures in the Figures 1 and 2 when comparing the years 2001 and 2014) and in 4 indicators decrease (the gross birth rate, employment rate, unemployment rate and the number of freelancers per 1000 inhabitants).

The highest regional disparities in IG were recorded at the end of the reporting period in 2014 respectively 2013 (when it was the last year of the assessment) in the following indicators: labour productivity per employee in industry (0.2847), the number of organizations focused on generating profit per 1000 inhabitants (0.2767), completed dwellings (0.2523), creation of GDP per capita (0.2282) and unemployment rate (o.1874). The highest values of regional disparities in the above mentioned indicators, with minor variations were also confirmed in 2014 respectively 2013 in CV: the number of organizations focused on generating profit (0.7788), labour productivity per employee in industry (0.5807), creation of GDP per capita (0.5710), completed dwellings (0.5081), labour productivity per employee in construction (0.3765) and unemployment rate (0.3537).

When comparing the increase of regional disparities expressed by IG and CV (Figure 3), the highest growth was recorded in the following indicators: labour productivity per employee in construction (IG by $45.2 \%$, CV by $50.7 \%)$, completed dwellings per 1000 inhabitants (by $43.0 \%$, by $45.2 \%$ ), net monthly expenses per capita (by $37.2 \%$, by $24.6 \%$ ), net monthly income per capita (by $33.2 \%$, by $17.8 \%$ ) and labour productivity per employee in industry (by $26.0 \%$, by $8.8 \%$ ).

The opposite trend in the development of regional disparities during the reporting period was recorded in 4 indicators. The value of regional disparities in these indicators compared to other indicators was at the average respectively below average (the unemployment rate $-5^{\text {th }}$ place, the number of freelancers per 1000 inhabitants $-7^{\text {th }}$ place, the gross birth rate $-10^{\text {th }}$ place, the employment rate $-13^{\text {th }}$ place). The decrease of disparities in these indicators was following: the employment rate (IG decreased by $25.4 \%, \mathrm{CV}$ by $28.0 \%$ ), the gross birth rate (a decrease by $23.9 \%, 25.2 \%$ ), the number of freelancers per 1000 inhabitants (a decrease by $21.2 \%, 31.1 \%$ ) and the unemployment rate (by $2.6 \%, 5.2 \%$ ).

\section{Conclusion}

The above presented analysis of development of regional disparities in regions of SR confirmed the divergence tendencies in regional development in Slovakia. Although since 2006 respectively 2008 is a noticeable relative stabilization of regional disparities, within the entire reporting period they increased.

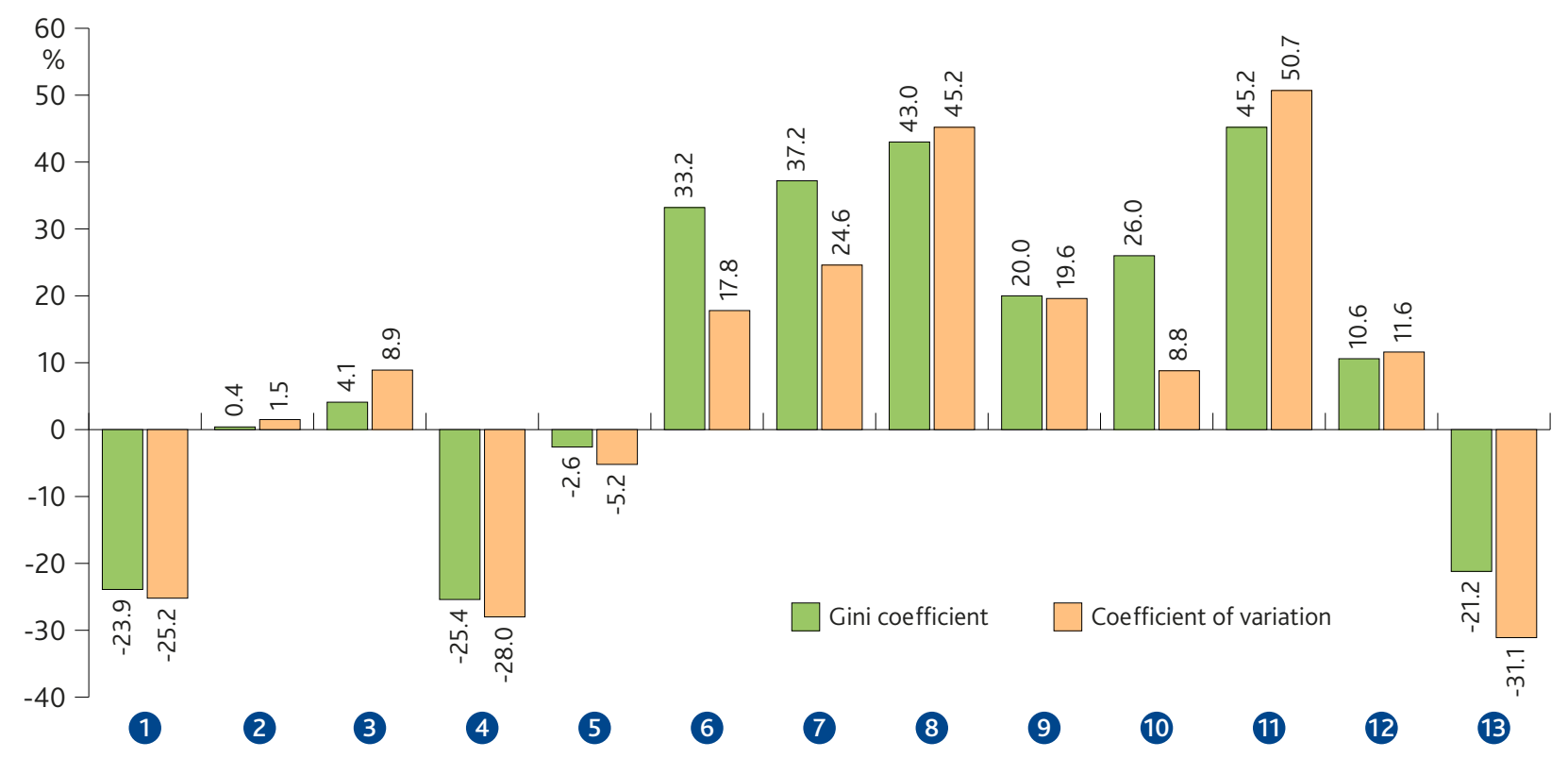

Figure 4. Increase respectively decrease (\%) of the values of the Gini coefficient and coefficient of variation between 2001-2014. Explanation: A value 0 on the $x$-axis represents the state of regional disparities in individual indicators in 2001, plus values indicate an increase in disparities, minus values a decrease 1- the gross birth rate, 2 - the average monthly wage, 3 - monthly labour cost per employee 4 - employment rate, 5 - unemployment rate, 6 - net monthly income per capita, 7 - net monthly expenses per capita, 8 - completed dwellings per 1000 inhabitants, 9 - creation of GDP per capita, 10 - labour productivity per employee in industry, 11 - labour productivity per employee in construction, 12 - organizations focused on generating profit per 1000 inhabitants, 13 - number of freelancers per 1000 inhabitants. Note: For indicators - monthly labour costs per employee, net monthly income per capita, net monthly expenses per capita, gross domestic product per capita was used the last available year with data (2013)

Source: www.statistics.sk, www.ueos.sk/mvrr.sk/isvov/, own calculation 
These facts are the result of the differentiated development of regional structure of Slovakia.

The state through active regional policy does not help to level this uneven distribution of regional forces. In spite of the use of some exogenous factors to which the state has a significant impact and influence such as investment stimuli, foreign direct investment and the structural funds, there is no remedy of spatial economic disparities and gradual regional convergence. On the contrary, the strategic location of foreign investments at a time of economic conversion in the north-western part of Slovakia accompanied by investment stimuli aggravated and increased regional disparities. After 2006, and especially after the beginning of the global economic crisis in the world in 2008, Slovakia experienced some changes. It was recorded relatively stopping of the rise of regional disparities respectively a slight decrease. This argument raises a certain amount of optimism in terms of further development of the Slovak regions, but also doubt whether this trend was caused by the actual starting of the socio-economic development in the least developed regions of south-eastern Slovakia. But the reality is more prosaic, as development did not occur in the most backward regions of Slovakia, but the global economic crisis was significantly reflected by the stagnation respectively by a decline in the economically developed regions of Slovakia, which more sensitively reacted to economic changes.

The answer to the question of divergent or convergent tendencies of regional disparities in Slovakia is in favour of increasing regional disparities between regions. Although the answer is quite clear, it is important to note that the whole process of development during the reporting period consisted of two quite distinct stages. On the one hand, during the general economic prosperity until 2006 respectively the beginning of the crisis in 2008 grew much faster prosperous regions and also regional disparities, on the other hand, there came a crisis period marked by economic problems in the regions of Slovakia (with a greater impact on the more developed regions) and stabilization respectively a slight decrease of regional disparities. The question that arises in this context is whether the trend of stagnation of increase of disparities between the Slovak regions in recent years is the result of the beginning of real convergence tendencies which have already been discussed by several authors Blažek, Csank (2007), Korec (2009), Matlovič, Matlovičová (2011) or it is just the result of a specific situation caused by the economic crisis and after its final end there will be a faster recovery of more developed regions of north-western Slovakia and increase of regional disparities. The answer to this question will bring the development in the coming period.

\section{References}

Alesina, A., Spolaore, E. 2003. The size of nations. MIT Press, Cambridge, MA.

Ancuţa, C. 2012. Aspects regarding the socio-economic indicators used in approaching the territorial disparities. Geographica Pannonica 16, 1, 26-34.

Blažek, J. 1996. Inter-regional disparities in the Czech republic during the transition. Geografie - Sborník CGS, č. 4/1996, 265-277. (in Czech with English summary)

Blažek, J., Csank, P. 2007. A new phase of regional development in the Czech republic? Sociologický časopis 43, 5, 945-965. (in Czech)

Blažek, J., Uhlír, D. 2002. Theories of regional development. Karolinum, Praha, 212 pp. (in Czech with English summary)

Buček, M., Rehák, Š., Tvrdoň, J. 2010. Regional economics and policy. Iura Edition, Bratislava, $269 \mathrm{pp}$. (in Slovak with English summary)

Croward, T. 2002. Defining the category of „small“ states. Journal of International Development 14, 143179.

Eastearly, W., Kraay, A. 20oo. Small states, small problems? Income, growth and volatility in small states. World Development 28, 11.

Felsenstein, D., Portnov, B. (eds.) 2005a. Regional disparities in small countries. Springer, $333 \mathrm{pp}$.

Felsenstein, D., Portnov, B. 2005b. Understanding regional inequalities in small countries. Regional Studies 39, 5, 647-658.

Gajdoš, P. 2001. On selected problems of transformation of social-spatial situation in Slovakia in 1990 . Sociológia 33, 2, 185-206. (in Slovak with English summary)

Dunfort, M. 1993. Regional disparities in the european community: revidence from the Regio Databank. Regional Studies 27, 727-743.

Hamada, R. 2016. Selected process and methods measurement and evaluation of regional disparities. Regionální rozvoj mezi teorií a praxí, 1, http://www. regionalnirozvoj.eu/201401/vybrane-sposoby-metody-merania-hodnotenia-regionalnych-disparit (visited 25.2.2016). (in Slovak)

Hampl, M. et al. 2001. Regional development: specifics of Czech transformation, european integration and general theory. UK Praha, 328 pp. (in Czech)

Hampl, M. 2010. The regional differentiation of society: general types of development processes. Číslo 1, ročník 115, 1-20. (in Czech with English summary)

Hampl, M., Müller, J. 2011. Societal transformation and regional differentiation in Czechia: developments in the distribution of job opportunities and population. Geografie, číslo 3, ročník 116, 212-230. (in Czech with English summary) 
Horká, L. 2012. Regional disparities and convergence in the context of the EU cohesion policy. Sborník př́spěvků - XV. mezinárodní kolokvium o regionálních vědách. Valtice 20.-22.6.2012, 28-35. (in Czech)

Huang, Y., Leung, Y. 2009. Measuring regional inequality: A comparison of coefficient of variation and Hoover concentration index. The Open Geography Journal 2, 25-34.

Hudec, O., Bilá, A. 2008. Regional environmental and innovation disparities in the European union. Životné prostredie 42, 1, 11-14. (in Slovak)

Ianoş, I., Petrişor, A. I., Zamfir, D., Cercleux, A. L., Stoica, I. V., Tălângă, Ch. 2013. In search of a relevant index measuring territorial disparities in a transition country. Romania as a case study. Die Erde Journal of the Geographical Society of Berlin 144, 1, 69-81.

Kebza, M., Kubeš, J., Nováček, A. 2015. East-west gradient of social and economic space defferentiation in Hungary. Sborník příspěvků - XVIII. mezinárodní kolokvium o regionálních vědách. Hustopeče 17.19.6.2015, 41-48. (in Czech)

Kallioras, D. 2010. Regional inequalities in the new European Union member-states: Is there a „population size“ effect? European Spatial Research and Policy 17, 2, 107-116.

Klamár, R. 2008. Slovakia and the analysis its disparities. In: Acta Facultatis Studiorum Humanitatis et Naturae Univesitatis Prešoviensis, Prírodné vedy, Folia Geographica 12, Prešov, 145-163.

Klamár, R. 2011. Development of regional disparities in Slovakia with special regard to the region of Eastern Slovakia. FPHV PU, Prešov. Acta Facultatis Studiorum Humanitatis et Naturae Univesitatis Prešoviensis, Prírodné vedy, Folia Geographica 18, 89-170. (in Slovak with English summary)

Korec, P. 2005. Regional Development of Slovakia in the period 1989 - 2004. Geografika, Bratislava, 228 pp. (in Slovak)

Korec, P. 2009. Sectoral changes of economics of Slovakia in first of societal transformation in regional point of view. Geographia Moravica 1, 11-26. (in Slovak with English summary)

Kožiak, R., Král', P., Križo, P. 2012. GDP as the only indicator EU regional policy? Sborník příspěvků XV. mezinárodní kolokvium o regionálních vědách. Valtice 20.-22.6.2012, 19-27. (in Slovak)

Kutscherauer, A. 2008. Disparities and their impact on regional development. In: Regional disparities in territorial development of the Czech Republic their origin, identification and elimination. VŠB Technická univerzita Ostrava, Ekonomická fakulta, Šilheřovice, 1-11. (in Czech)
Manic, E., Popovic, S., Molnar, D. 2012. Regional disparities and regional development: the case of Serbia. Mitteilungen der Österreichischen Geographischen Gesellschaft 154, 191-211.

Matlovič, R. 2004. Prešov region in the context of selected regional disparities in Slovakia. In: Kuzmišin, P., ed., Podnikatel'ské prostredie a regionálne aspekty rozvoja, II., Manacon, Prešov, 88-107. (in Slovak)

Matlovič, R., Matlovičová, K., Klamár, R. 2008. Development of regional disparities in Slovakia at the beginning of $21^{\text {st }}$ century based on the selected indicators. Regionální studia č. 2, Vysoká škola ekonomická v Praze, Praha, 2-12. (in Slovak with English summary)

Matlovič, R., Matlovičová, K. 2005. Development of regional disparities in Slovakia and problems of regional development in the Prešov region. FPHV PU, Prešov. Acta Facultatis Studiorum Humanitatis et Naturae Univesitatis Prešoviensis, Prírodné vedy, Folia Geographica 8, 66-89. (in Slovak with English summary)

Matlovič, R., Matlovičová, K. 2011. Regional disparities and their solution in Slovakia in the various contexts. FPHV PU, Prešov. Acta Facultatis Studiorum Humanitatis et Naturae Univesitatis Prešoviensis, Prírodné vedy, Folia Geographica 18, 8-88. (in Slovak with English summary)

Mariš, M. 2016. Regional disparities in V4 countries and development powers. Regionální rozvoj mezi teorií a praxí, 1, http://www.regionalnirozvoj. $\mathrm{eu} / 201401 /$ regionalne-disparity-v-priestore-krajin-v4-hnacie-sily-rozvoja (visited 4.3.2016). (in Slovak)

Měrtlová, L. 2012. Comparison of the regional disparities of the Czech republic regions. Sborník příspěvků - XV. mezinárodní kolokvium o regionálních vědách. Valtice 20.-22.6.2012, 81-90. (in Czech)

Michálek, A. 2012a. Theoretical and conceptual bases of space and regional disparities research. Acta Geographica Universitates Comenianae 56, 1, 25-43. (in Slovak with English summary)

Michálek, A. 2012b. Some methods for measuring megional disparities. Geografický časopis 3, 219-235. (in Slovak with English summary)

Michaeli, E., Matlovič, R., Ištok, R., Klamár, R., Hofierka, J., Mintálová, T., Mitríková, J. 2010. Regional development for geographers. Prešovská univerzita, Prešov, 717 pp. (in Slovak)

Nemes-Nagy, J. 2006. Regional inequalities: general models and the case of the transition countries. Romanien Review of Regional Studies 2, 1, 23-34.

OECD 2002. Geographic concentration and territorial disparity in OECD Countries. OECD Publi- 
cations Service, Paris, 25 s. http://www.oecd.org/ (navštívené 16.5.2013).

Orayen, R. E., Pascual, P., Rapún, M. 2007. The dynamics of regional disparities in entral and Eastern Europe during transition. European Planning Studies 15, 1397-1421.

Petrakos, G. 2001. Patterns of regional inequality in transition countries. European Planning Studies 3, 359-383.

Petrakos, G. 2008. Regional inequalities in Europe: reflections on evidence, theory and policy. Town Planning Review 79, 5, 7-13.

Petrakos, G., Artelaris, P. 2009. European regional convergence revisited: a weighted least squares approach. Growth and Change 40, 2, 314-331.

Poledníková, E., Lelková, P. 2012. Evaluation of regional disparities in Visegrad Four countries, Germany and Austria using the cluster analysis. Sborník př́spěvků - XV. mezinárodní kolokvium o regionálních vědách. Valtice 20.-22.6.2012, 36-45.

Poledníková, E. 2014. Multicriteria analysis of regional disparities in the context of the EU cohesion. Sborník příspěvků - XVII. mezinárodní kolokvium o regionálních vědách. Hustopeče 18.-20.6.2014, 54-61.

Puljiz J., Maleković, S. 2007. Regional income and unemployment disparities in Croatia, Conference proceedings, ${ }^{\text {th }}$ International Conference: Enterprise in Transition. University of Split, May 24-26.

Rajč́ková, E., Švecová, A. 2010. Regional disparities in Slovakia and their (reduction) solution by financial instruments of EU in the reforming period 2007-2013. In: Fňukal, M., Frajer, J., Hercik, J., eds., 50 let geografie na Přírodovědecké fakultě Univerzity Palackého v Olomouci. UP Olomouc, 523-532. (in Slovak)

Rosičová, K., Rosič, M., Török, Z., Hajdu, M. 2005. Slovakia, the most attractive investment location in Europe, CEBIS - Central European Business Services, Košice, $99 \mathrm{~s}$.

Sojková, Z. 2006. Investigation of regional disparities in the European Union at the NUTS II level. International scientific days 2006 - "Competitivness in the EU - Challenge for the $\mathrm{V}_{4}$ countries". Faculty of Economic and Management SAU in Nitra, 14641469, http://www.fem.uniag.sk/mvd2006/zbornik/ sekcia7/s7_sojkova_zlata_297.pdf (visited 15.5.2013). (in Slovak with English summary)

Svatošová, L., Boháčková, I., 2012. Methodological approaches to evaluation of regional disparities. Sborník příspěvků - XV. mezinárodní kolokvium o regionálních vědách. Valtice 20.-22.6.2012, 112-119. (in Czech)

Sloboda, D. 2006. Slovakia and regional disparities. Theories, regions, indicators, methods. Konzervatívny inštitút M. R. Štefánika, Bratislava, 49 p. (in Slovak)

Szörfi, B. 2007. Development and regional disparities - testing the Williamson curve hypothesis in the European Union. Kopint-Tárki Economic Research Institute, Budapest, Hungary, p.22, http:// www.oenb.at/de/img/feei_2007_2_szoerfi_tcm1479074.pdf (visited 25.8.2008).

Smętkowski, M. 2013. Regional disparities and development dynamics of cee regions in the period of prosperity and austerity. file://C:/Users/Rado/ Downloads/Regional\%2odisparities\%20and\%20 development\%2odynamics\%20of\%2oCEE\%2oregions\%20in\%2othe\%2operiod\%20of\%2oeconomic\%2oprosperity\%2oand\%20crisis.pdf (visited 6.6.2015).

Smętkowski, M., Wójcik, P. 2012. Regional convergence in Central and Eastern European countries - a multidimensional approach. European Planning Studies 20, 6, 923-939.

Štika, R. 2004. Regional disparities in Czechia in 1990 s in modern development context. Geografie - sborník České geografické společnosti 109, 1, 15-26. (in Czech with English summary)

Uzzoli, A., Szilágyi, D. 2009. Life expectancy and its regional inequalities in Hungary. Geographica Pannonica 13, 4, 127-136.

Williamson, J. G. 1965. Regional inequality and the process of national development: a description of patterns. Economic Development and Cultural Change 13, 3-45.

Zdražil, P., Kraftová, I. 2012. Do the V4 regions convergence? Sborník prríspěvků - XV. mezinárodní kolokvium o regionálních vědách. Valtice 20.22.6.2012, 48-58. (in Czech)

Statistical Yearbook of the Slovak Republic 2012. Veda, Bratislava, 675 pp. (in Slovak)

http://www.build.gov.sk/mvrrsr/source/document/ o01436.pdf

www.economy.gov.sk

www.eurostat.com

www.rail.sk

www.sario.sk

www.statistics.sk

www.ueos.sk/mvrr.sk/isvov/ 